\title{
INFEKSI JAMUR KUKU (ONYCHOMYCOSIS) PADA LANSIA DI PANTI SOSIAL TRESNA WERDHA WANA SERAYA
}

\section{ONYCHOMYCOSIS IN ELDERLY AT WANA SERAYA NURSING HOME}

\author{
I Nyoman Aryasa, Ni Wayan Desi Bintari, I Dewa Agung Ketut Sudarsana \\ Program Studi Teknologi Laboratorium Medis Program Diploma Tiga \\ STIKes Wira Medika Bali
}

\begin{abstract}
ABSTRAK
Onychomycosis merupakan infeksi pada lempeng kuku yang dapat disebabkan oleh jamur dermatofita (Tinea unguium), non dermatofita atau yeast. Infeksi onychomycosis menyebabkan kerusakan pada kuku yang menyebabkan lempeng kuku menebal, rapuh dan mudah hancur. Penelitian ini bertujuan untuk gambaran onychomycosis pada lansia di Panti Sosial Tresna Werdha (PSTW) Wana Seraya. Jenis penelitian yang digunakan adalah penelitian deskriptif. Pengambilan sampel penelitian dilakukan di Panti Sosial Tresna Werdha (PSTW) Wana Seraya di Jl. Gemitir No.66, Kesiman Kertalangu, Denpasar Timur, Kota Denpasar, Bali. Sampel dianalisa di Lab. Parasitologi Teknologi Laboratorium Medis STIKes Wira Medika Bali. Pemeriksaan menggunakan teknik pengamatan langsung menggunakan pewarna kalium hidroksida $(\mathrm{KOH}) 10 \%$ pada kerokan kuku 15 orang responden yang memenuhi kriteria inklusi dan eksklusi. Hasil pemeriksaan menunjukkan terdapat 1 responden $(6,67 \%)$ yang positif onychomycosis dengan ditemukannya hifa pada pengamatan mikroskopis preparat kerokan kuku. Sementara itu 14 sampel lainnya $(93,33 \%)$ dinyatakan negatif. Hasil screening pada penelitian ini menunjukkan lansia di PSTW Wana Seraya telah memiliki hygiene diri yang baik khususnya dalam memelihara kebersihan kuku kaki dan tangan sehingga mengurangi faktor resiko terjadinya infeksi jamur kuku.
\end{abstract}

Kata Kunci : Jamur kuku (Onychomycosis), Dermatophyta, Kalium Hidroksida (KOH) $10 \%$

\section{ABSTRACT}

Onychomycosis is an infection of the nail plate that can be caused by dermatophyte fungi (Tinea unguium), non dermatophytes or yeast. Onychomycosis infection causes damage to the nails which causes the nail plate to thicken, brittle and break easily. This study aims to describe onychomycosis in the elderly at Tresna Werdha Social Home (PSTW) Wana Seraya. This type of research is descriptive research. Sampling was conducted at the Tresna Werdha Social Home (PSTW) Wana Seraya on 66 Gemitir St., Kesiman Kertalangu, East Denpasar, Denpasar City, Bali. Samples analyzed in Parasitology Laboratory STIKes Wira Medika Bali. Sampels examination using direct observation techniques using 10\% 
Bali Medika Jurnal.

Vol 7 No 1, 2020: 116-124

ISSN : 2615-7047

DOI: https://doi.org/10.36376/bmj.v7i1

potassium hydroxide $(\mathrm{KOH})$ dye on nail scrapings on 15 respondents who met the inclusion and exclusion criteria. The results of the examination showed that there was 1 respondent (6.67\%) who tested positive for onychomycosis with the discovery of hyphae on microscopic observation of nail scrapings preparations. Meanwhile 14 other samples $(93.33 \%)$ were stated negative. The screening results in this study show that the elderly in PSTW Wana Seraya have had good personal hygiene, especially in maintaining the cleanliness of toenails and hands, thereby reducing the risk factors for nail fungus infection.

Keywords: Fungal nail infection (Tinea unguium), Direct Observation, Potassium hydroxide stain, Elderly

Alamat Korespondensi : Jl. Kecak No.9A, Tonja, Kec. Denpasar Utara, Kota Denpasar, Bali 80239 Email : aryasa.nyoman@yahoo.com

\section{PENDAHULUAN}

Penyakit infeksi oleh jamur hingga saat ini masih cukup banyak terjadi di masyarakat. Resiko infeksi jamur tersebut sangat dipengaruhi oleh iklim Indonesia yang memiliki tingkat humiditas tinggi. Di samping itu kondisi sosial ekonomi yang belum merata juga berpengaruh terhadap hygiene personal masyarakat yang berkorelasi terhadap angka kejadian infeksi (Hermawan \& Widyanto, 2000). Infeksi oleh jamur yang hingga saat ini kurang disadari oleh masyarakat adalah infeksi yang terjadi pada kuku atau dikenal dengan onychomycosis (Setianingsih et al., 2015). Penyakit ini dapat terjadi pada beberapa bagian kuku seperti matriks, nail bed atau nail plate yang mengakibatkan rasa nyeri, tidak nyaman dan tampilan kuku yang kurang baik (Rohmah \& Bariyah, 2012).

Onychomychosis dapat disebabkan oleh infeksi jamur dermatofita, nondermatofita serta yeast (Budimulja et al., 2007). Jamur dermatofita yang paling banyak menimbulkan infeksi diantaranya Trichophyton rubrum (70\%), Trichophyton mentagrophytes (19,8\%) dan Epidermophyton floccosum (2,2\%). Adapun jamur dermatofita lain yang pernah dilaporkan diantaranya Trichophyton tonsurans, Trichophyton violaceum, Trichophyton verrucosum, Microsporum gypseum dan Trichophyton soudanacea. Infeksi jamur kuku yang disebabkan oleh jamur dermatophyta tersebut diistilahkan dengan Tinea unguium. Adapun kelompok non-dermatofita yang paling sering dilaporkan meliputi kelompok Aspergillus sp. dan Candida albicans (Bintari et al., 2019; Putra, 2008). Infeksi jamur tersebut menyebabkan terjadinya perubahan warna pada kuku menjadi putih, kuning atau kecoklatan, kuku mengalami onycholisis, pecah-pecah dan tidak rata Infeksi onikomikosis menurut ahli tidak menyebabkan mortalitas, namun menimbulkan gangguan klinis yang signifikan, mengurangi estetika, bersifat kronis dan sulit diobati. Hal tersebut selanjutnya akan mengganggu kenyamanan dan menurunkan kualitas hidup penderita (Setianingsih et al., 2015).

Pemeriksaan penunjang terhadap Tinea unguium untuk penegakan diagnosis menurut Rizkya et al. (2015) dapat dilakukan melalui pengamatan jamur langsung (direct microscopy) pada spesimen kerokan kuku atau melalui kultur jamur. Pemeriksaan direct menggunakan larutan kalium hidroksida $(\mathrm{KOH})$ yang 
membantu melarutkan jaringan epitel (Wolff \& Johnson, 2010). Pemeriksaan mikroskopis langsung meskipun bukan baku standar dalam pemeriksaan Tinea unguium namun menurut Noviandini et al. (2017) sangat baik digunakan untuk pemeriksaan awal karena cepat, sederhana dan mudah dilakukan.

Menurut Rohmah \& Bariyah (2012), pertambahan usia merupakan salah satu faktor resiko yang berkorelasi terhadap angka kejadian onychomycosis. Pada tahap lansia seseorang akan mengalami penurunan kemampuan kerja, imunitas dan fungsi organ-organ tubuh (Kurnianto, 2015). Hal tersebut menurut Ramadhan \& Sabrina (2016) akan mengakibatkan timbulnya gangguan dalam mencukupi kebutuhan hidupnya khususnya kebutuhan kebersihan diri. Padahal personal hygiene sangat penting dalam usaha mencegah timbulnya penyakit mengingat sumber infeksi dapat muncul bila aspek kebersihan kurang mendapat perhatian. Pemeriksaan awal atau screening terkait onychomycosis pada lansia khususnya yang tinggal di Panti Sosial Tresna Werdha sangat jarang dilakukan. Padahal screening awal dapat mencegah infeksi serius dan mencegah terjadinya kerusakan kuku secara permanen. Berdasarkan hal tersebut penelitian ini bertujuan untuk mengetahui gambaran hasil pemeriksaan infeksi onychomycosis pada lansia di PSTW Wana Seraya melalui pemeriksaan jamur kuku dengan teknik pengamatan langsung spesimen kerokan kuku.

\section{METODE PENELITIAN}

Penelitian dilakukan di Laboratorium Parasitologi Program Studi Teknologi Laboratorium Medis Program Diploma III STIKes Wira Medika Bali pada AprilJuni 2019.

\section{Populasi dan sampel}

Penelitian merupakan jenis penelitian deskriptif yang digunakan untuk menggambarkan atau menganalisis suatu hasil penelitian tetapi tidak digunakan untuk membuat kesimpulan yang lebih luas. Populasi dalam penelitian ini adalah lansia yang merupakan anggota Panti Sosial Tresna Wredha (PSTW) Wana Seraya yang berjumlah 32 orang. Metode sampling yang digunakan adalah purposive sampling Sampel yang digunakan adalah sampel yang memenuhi kriteria inklusi dan eksklusi sebanyak 15 responden. Kriteria inklusi meliputi lansia yang mampu berkomunikasi dengan baik; lansia dengan salah satu kondisi kuku diantaranya berwarna kuning/ kecoklatan, tidak mengkilat, tidak rata atau onycholisis. Sedangkan kriteria ekslusi meliputi lansia dengan gangguan mental dan demensia serta lansia yang berada di ruang isolasi khusus.

\section{Pengambilan sampel, pengumpulan dan analisa data}

Responden yang akan diambil sampelnya dipandu untuk mengisi informed consent, kuisioner dan diberikan penjelasan terkait pemeriksaan yang akan dilakukan. Kuku kaki yang akan diambil sampelnya dibersihkan dengan kapas alkohol 70\%. Bagian kuku yang bergejala diambil sampelnya dengan cara dikerok dengan menggunakan skalpel steril dan disposable dengan arah dari atas ke bawah. Sampel ditampung pada kertas kering dan dimasukkan ke dalam pot steril untuk selanjutnya dilakukan pemeriksaan di laboratorium. Pemeriksaan sampel kerokan 
Bali Medika Jurnal.

Vol 7 No 1, 2020: 116-124

ISSN : 2615-7047

DOI: https://doi.org/10.36376/bmj.v7i1

kuku dengan menggunakan direct microscopy menggunakan larutan $\mathrm{KOH} 10 \%$.

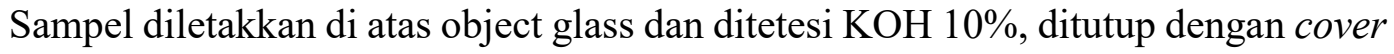
glass dan didiaman selama 30 menit. Preparat selanjutnya diamati di bawah mikroskop dan dilakukan pengamatan terhadap ada atau tidaknya hifa, konidia atau sel yeast/ ragi. Data hasil identifikasi yang telah diperoleh selanjutnya dianalisa dan disajikan dalam bentuk tabel.

\section{HASIL DAN PEMBAHASAN}

\section{HASIL PENELITIAN}

Hasil pemeriksaan jamur kuku pada spesimen kerokan kuku lansia dengan metode pengamatan langsung ditemukan 1 sampel $(6,67 \%)$ yang hasilnya positif dan sebanyak 14 sampel (93,33\%) negatif (Tabel 1). Sampel positif teridentifikasi pada responden wanita (Sampel 5) dengan ditemukannya hifa pada sampel kerokan kuku kaki berdasarkan pengamatan mikroskopis (Gambar 1). Sedangkan sebanyak 14 sampel dinyatakan negatif karena berdasarkan pengamatan langsung tidak ditemukan adanya hifa atau konidia pada preparat kerokan kuku.

Tabel 1. Hasil Identifikasi Kejadian Jamur Kuku (Onychomycosis)

\begin{tabular}{ccccc}
\hline No. & Kode sampel. & Umur (Tahun) & Jenis kelamin & Hasil \\
\hline 1 & Sampel 1 & 80 & $\mathrm{~L}$ & Negatif \\
\hline 2 & Sampel 2 & 85 & $\mathrm{P}$ & Negatif \\
\hline 3 & Sampel 3 & 68 & $\mathrm{P}$ & Negatif \\
\hline 4 & Sampel 4 & 70 & $\mathrm{P}$ & Negatif \\
\hline 5 & Sampel 5 & 76 & $\mathrm{P}$ & Positif \\
\hline 6 & Sampel 6 & 67 & $\mathrm{P}$ & Negatif \\
\hline 7 & Sampel 7 & 80 & $\mathrm{~L}$ & Negatif \\
\hline 8 & Sampel 8 & 73 & $\mathrm{~L}$ & Negarif \\
\hline 9 & Sampel 9 & 60 & $\mathrm{P}$ & Negatif \\
\hline 10 & Sampel 10 & 85 & $\mathrm{P}$ & Negatif \\
\hline 11 & Sampel 11 & 85 & $\mathrm{~L}$ & Negatif \\
\hline 12 & Sampel 12 & 72 & $\mathrm{P}$ & Negatif \\
\hline 13 & Sampel 13 & 57 & $\mathrm{P}$ & Negatif \\
\hline 14 & Sampel 14 & 77 & $\mathrm{P}$ & Negatif \\
\hline 15 & Sampel 15 & 75 & $\mathrm{P}$ & Negatif \\
\hline
\end{tabular}



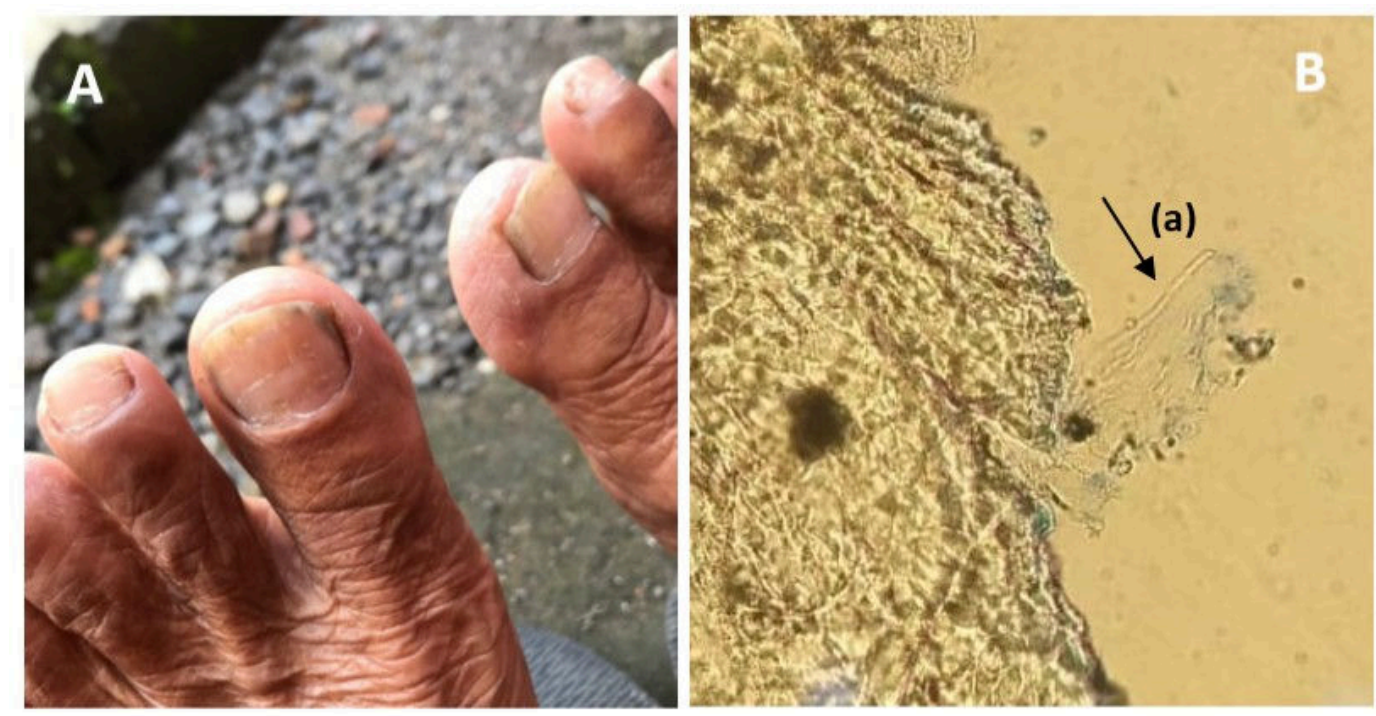

Gambar 1.

Gejala klinis Jamur Kuku (A) dan hasil pengamatan mikroskopis (B) pada sampel 5. Hifa Jamur non dermatofita ditunjukkan pada anak panah (a)

\section{PEMBAHASAN}

Onychomycosis merupakan infeksi jamur pada kuku yang disebabkan oleh jamur dermatofita, jamur non-dermatofita dan ragi (Anugrah, 2016). Hasil pengamatan metode langsung untuk identifikasi jamur kuku yang dilakukan terhadap 15 sampel kerokan kuku kaki lansia di Panti Sosial Tresna Wredha (PSTW) Wana Seraya diketahui sebanyak 1 sampel (6,67\%) positif jamur kuku dan 14 sampel $(93,33 \%)$ lainnya negatif. Hasil positif ditunjukkan dengan ditemukannya hifa pada preparat kerokan kuku dengan metode pengamatan langsung. Hasil tersebut sesuai dengan gejala klinis yang ditunjukkan yaitu kuku responden berwarna kuning kecoklatan dan terdapat penumpukan sisa jaringan dibawah kuku. Sedangkan pada 14 sampel lainnya negatif jamur kuku dengan tidak ditemukannya hifa pada preparat kerokan kuku dengan metode pemeriksaan langsung.

Onychomycosis merupakan infeksi jamur yang kronis pada kuku jari kaki atau kuku jari tangan. Biasanya onychomycosis disertai dengan infeksi jamur yang lama pada kaki. Kuku menjadi tebal,rapuh, dan tidak mengkilat. Lempeng kuku menjadi rusak dan berubah warna menjadi kehitaman, kekuningan atau suram. Tinea unguium (onychomycosis, ringworm of the nail) adalah jamur dermatofitosis yang paling sukar dan lama disembuhkan karena kuku terinfeksi menjadi rusak dan rapuh dan bentuknya tidak normal. Di bagian bawah kuku akan menumpuk sisa jaringaan kuku yang rapuh sehingga tampak seperti kotoran (Kurniati, 2008).

Pada penelitian ini sampel kuku kaki yang positif onychomycosis adalah responden perempuan. Hasil tersebut mendukung penelitian oleh Setianingsih et al. (2015) di Kecamatan Tanah Siang, Provinsi Kalimantan Tengah yang menyatakan bahwa Tinea unguium lebih banyak menginfeksi perempuan. Hasil penelitiannya menyatakan bahwa dilihat dari gambaran jenis kelamin subjek penelitian, diperoleh bahwa proporsi perempuan yang terinfeksi lebih banyak di dibandingkan laki-laki yaitu sebesar $71 \%$ pada perempuan dan $29 \%$ pada laki-laki. Bitew \& Wolde (2019) 
menyatakan penelitian terkait faktor resiko jenis kelamin terhadap kejadian infeksi onychomycosis perlu dipelajari lebih lanjut. Beberapa studi melaporkan bahwa kejadian onychomycosis lebih beresiko pada pria (Ahuja et al., 2011; Satpathi et al., 2016), namun hasil studi lainnya melaporkan hal yang sebaliknya (Sigurgeirsson \& Baran, 2013). Faktor jenis kelamin lebih lanjut menurut Bitew \& Wolde (2019) dalam manifestasi klinisnya terhadap onychomycosis sangat tergantung pada kontribusi faktor lain yang saling berkaitan. Beberapa faktor tersebut seperti trauma pada kuku yang disebabkan oleh aktivitas luar ruangan atau adanya penyakit bawaannya yang dapat memperburuk infeksi.

Berdasarkan wawancara dan pengisian kuisioner oleh responden diketahui sebanyak 73,33\% lansia sudah secara rutin melakukan personal hygiene yang baik seperti mencuci tangan dan kaki sesudah melakukan aktifitas, menggunakan sandal/ alas kaki, mandi secara teratur dan rutin memotong kuku tangan dan kaki. Sementara itu sebanyak 26,67 responden belum menerapkan hygiene personal dengan baik khususnya terkait kebersihan kuku tangan dan kaki. Kurangnya kesadaran terhadap kebersihan individu tersebut dapat menjadi faktor resiko meningkatkanya infeksi jamur pada lempeng kuku atau kulit. Marsaoly et al. (2014) menyatakan keterkaitan tersebut disebabkan karena pada usia lanjut dapat terjadi perubahan fungsi imunitas tubuh termasuk penurunan respon imunitas untuk melawan infeksi terhadap virus, bakteri dan jamur sehingga dapat memiliki risiko yang lebih besar terhadap penyakit akibat infeksi maupun penyakit kronik lainnya.

Pada penelitian ini hifa jamur yang diamati pada sampel positif (sampel nomor 5) memiliki struktur tidak bersekat atau aseptat. Onychomycosis dapat disebabkan oleh jamur dari kelompok non-dermatofita dan dermatofita. Nondermatofita yang paling sering dilaporkan meliputi kelompok Aspergillus sp dan Candida albicans. Penelitian oleh Soetojo \& Astari (2016) menyatakan angka kejadian kandidiasis kuku di RSUD Dr. Soetomo pada 2011-2013 berjumlah 137 orang atau $0,65 \%$ dari keseluruhan kasus. Genus lain dari kelompok nondermatofita yang menyebabkan Tinea unguium diantaranya adalah Aspergillus sp. (Amirsyam, 2008; Bintari et al., 2019) dan Rhizopus sp. (Bongomin et al., 2018; Martínez-Herrera et al., 2015). Penelitian oleh Bitew (2018) menyatakan saat ini dermatofitosis cukup banyak disebabkan oleh kelompok non-dermatophytes. Dari 164 jenis jamur penyebab dermatofitosis yang diteliti sebanyak 47,6 \% nya merupakan kelompok non-dermatofita sedangkan 52,4\% nya termasuk ke dalam dermatofita. Sementara itu kelompok dermatofita yang dapat menyebabkan onychomycosis yang dikenal dengan Tinea unguium diantaranya adalah Trichophyton rubrum (70\%), Trichophyton mentagrophytes (19,8\%) dan Epidermophyton floccosum (2,2\%). Adapun jamur dermatofita lain yang pernah dilaporkan diantaranya Trichophyton tonsurans, Trichophyton violaceum, Trichophyton verrucosum, Microsporum gypseum dan Trichophyton soudanacea (Budimulja et al., 2007).

Pada penelitian ini pemeriksaan dilakukan dengan metode pengamatan langsung. Metode pengamatan langsung di dalam prosedurnya menggunakan $\mathrm{KOH}$ $10 \%$ yang berfungsi dalam melisiskan jaringan kuku sehingga mempermudah pengamatan keberadaan hifa atau konidia (Ruhimat et al., 2011). Penggunaan metode langsung dalam identifikasi jamur kuku ini memiliki kelebihan dan kekurangan. Metode langsung memiliki kelebihan yaitu pengerjaan yang singkat sehingga hasil pemeriksaan diperoleh dengan cepat. Sebaliknya kelemahan metode 
pengamatan langsung yaitu saat melakukan pengamatan terkadang hifa ataupun konidia jamur sulit ditemukan sehingga mempengaruhi hasil penelitian (Adiguna, 2017). Identifikasi jamur kuku selain melakukan pemeriksaan metode langsung juga disarankan untuk melakukan kultur jamur. Pemeriksaan kultur jamur memerlukan waktu inkubasi yang lama namun hasil positif dapat mudah diamati melalui pengamatan makroskopis koloni jamur di media SDA (Sabouraud Dextrose Agar).

\section{SIMPULAN DAN SARAN}

Pemeriksaan terhadap jamur kuku pada lansia di Panti Sosial TresnaWredha (PSTW) Wana Seraya dapat disimpulkan sebanyak 1 responden $(6,67 \%)$ positif Tinea unguium berdasarkan metode pengamatan langsung dan sebanyak 14 negatif $(93,33 \%)$. Penelitian lebih lanjut terkait identifikasi jamur penyebab infeksi sangat perlu dilakukan dengan menggunakan pemeriksaan kultur jamur.

\section{UCAPAN TERIMA KASIH}

Terimakasih kepada pengurus dan anggota lansia Panti Sosial Tresna Werdha Wana Seraya yang telah memberikan izin dan berpartisipasi secara aktif dalam penelitian ini.

\section{DAFTAR PUSTAKA}

Adiguna, P. D. M. S. (2017). Onychomycosis Overview. Basic Sciences and Therapeutic in Regenerative and Aesthetic Medicane (pp. 1-9). https://simdos.unud.ac.id/uploads/file_penelitian_1_dir/49d9e9c108b2e58 26d3fdc83b6954de3.pdf

Ahuja, S., Malhotra, S., \& Caroo, H. (2011). Etiological Agents of Onychomycosis From a Tertiary Care Hospital in Central Delhi India. Indian Journal of Fundamental and Applied Life Sciences, 1(11), 1-4.

Amirsyam, N. M. (2008). Mikologi dan Mikrologi Kedokteran Beberapa Pandangan Dermatologis. USU e-Repository.

Anugrah, R. (2016). Diagnostik dan Tatalaksana Onikomikosis. CDK-244, 43(9), 675-678. http://www.kalbemed.com/ DesktopModules/ Easy DNNNews/DocumentDownload.ashx?portalid=0\&moduleid $=471 \&$ articlei $\mathrm{d}=913 \&$ documentid $=1300$

Bintari, N. W. D., Suarsana, A., \& Wahyuni, P. R. (2019). Onychomycosis NonDermatofita Pada Peternak Babi di Banjang Paang Kaja dan Banjar Semaga Desa Penatih Kecamatan Denpasar Timur. Jurnal Kesehatan Terpadu, 3(1), 8-14.

https://jurnal.undhirabali.ac.id/index.php/kesehatan/article/view/708/630

Bitew, A. (2018). Dermatophytosis: Prevalence of Dermatophytes and NonDermatophytes Fungi from Patients Attending Arsho Advanced Medical Laboratory, Addis Ababa, Ethiopia. Hindawi Dermatology Research and Practice, 1-6.

Bitew, A., \& Wolde, S. (2019). Prevalence, Risk Factors, and Spectrum of Fungi in 
Patients with Onychomycosis in Addis Ababa, Ethiopha: A Prospective Study. Journal of Tropical Medicine, 1-6.

Bongomin, F., Batac, C. R., Richardson, M. D., \& Denning, D. W. (2018). A review of onychomycosis due to Aspergillus species. Mycopathologia, 183(3), 485-493. https://www.ncbi.nlm.nih.gov/pubmed/29147866

Budimulja, U., Djuanda, A., Hamzah, M., \& Aisah, A. (2007). Ilmu Penyakit Kulit dan Kelamin (5th ed.). Fakultas Kedokteran Universitas Indonesia.

Hermawan, D. A., \& Widyanto. (2000). Mengenal penyakit jamur kulit yang sering di temukan di Indonesia. Jurnal Meditek, 8(23), 46-59. http://ejournal.ukrida.ac.id/ojs/index.php/Meditek/article/download/929/10 08/

Kurnianto, D. (2015). Menjaga Kesehatan di Usia Lanjut. Jurnal Olahraga Prestasi, 11(2), 19-30. https://journal.uny.ac.id/index.php/ jorpres/article/view/5725

Kurniati, C. R. (2008). Etiopatogenesis Dermatofitosis. Jurnal Berkala Ilmu Kesehatan Kulit Dan Kelamin, 2, 43-50. http://journal.unair.ac.id/filer PDF/BIKKK_vol 20 no 3_des 2008_Acc_3.pdf

Marsaoly, R. R., Hari, E. D., Ariwangsa, G. N. A., Karmila, I. D., \& Adiguna, M. S. (2014). Profil Dermatomikosis Superfisialis Pada Pasien Geriatri Di Poliklinik Kulit Dan Kelamin RSUP Sanglah Denpasar Bali [Universitas Udayana].

https://simdos.unud.ac.id/uploads/file_penelitian_1_dir/f9438201850a02a9 37e942e156a9b6bc.pdf

Martínez-Herrera, Obed, E., Arroyo-Camarena, S., Tejada-García, D. L., PorrasLópez, C. F., \& Arenas, R. (2015). Onychomycosis due to opportunistic molds. An Bras Dermatol, 90(3), 334-337. http://www.scielo.br/scielo.php?script=sci_arttext\&pid=S036505962015000300334

Noviandini, A., Suyoso, S., \& Astari, L. (2017). Pemeriksaan Pewarnaan Kalium Hidroksida $(\mathrm{KOH}) 20 \%$ + Tinta Parker Blue-Black, Chicago Sky Blue (CSB), dan Kultur Jamur pada Dermatomikosis Superfisialis. Berkala Ilmu Kesehatan Kulit Dan Kelamin, 29(1), 21-30. https:/ejournal.unair.ac.id/BIKK/article/viewFile/4148/2796

Putra, I. B. (2008). Onikomikosis. Universitas Sumatera Utara.

Ramadhan, K., \& Sabrina, I. (2016). Hubungan Personal Hygiene Dengan Citra Tubuh Pada Lansia Di Desa Sepe Kecamatan Lage Kabupaten Poso. Jurnal Kesehatan Prima, 10(2), 1735-1748. http://poltekkes-mataram.ac.id/wpcontent/uploads/2016/12/8.-Kadar-1.pdf

Rizkya, A., Thaha, M. A., \& Rusmawardiana, R. (2015). Nilai Diagnostik Dermatophyte Strip Test pada Pasien Tinea Ungium. Jurnal Kedokteran Dan Kesehatan, 2(1), 99-103. https://media.neliti.com/media/publications/181660-ID-nilai-diagnostikdermatophyte-strip-test.pdf

Rohmah, A. I. N., \& Bariyah, K. (2012). Kualitas Hidup Lanjut Usia. Jurnal Keperawatan, 3(2), 120-132. http://ejournal.umm.ac.id/ index.php/keperawatan/article/view/2589

Ruhimat, U., Nurmalasari, A., Fadillah, A. F., \& Astuti, F. (2011). Pemeriksaan Jamur Penyebab Onikomikosis Pada Pemulung Di TPA. Jurnal Kesehatan, 
1-8. http://cdn.stikesmucis.ac.id/Undang Ruhimat PEMERIKSAAN JAMUR PENYEBAB Onikomikosis PADA PEMULUNG DI TPA KECAMATAN CIAMIS.pdf

Satpathi, P., Achar, A., Banerjee, D., Maiti, A., Sengupta, M., \& Mohata, A. (2016). Onychomycosis in Eastern India-study in a Peripheral Tertiary Care Centre. Journal of Pakistan Association of Dermatology, 23(1), 14-19.

Setianingsih, I., Arianti, D. C., \& Fadilly, A. (2015). Prevalensi, Agen Penyebab,dan Analisis Faktor Resiko Infeksi Tinea unguium pada peternak Babi di Kecamatan,Tanah Siang, Provinsi Kalimantan Tengah. Jurnal Epidemiologi Dan Penyakit Bersumber Binatang, 5(3), 155-161. https://www.neliti.com/publications/21418/prevalensi-agen-penyebab-dananalisis-faktor-risiko-infeksi-tinea-unguium-pada-p

Sigurgeirsson, B., \& Baran, R. (2013). The Prevalence of Onychomycosis in the Global Population - A Literature Study. Journal European Academy of Dermatology and Venereology, 1-2.

Soetojo, S., \& Astari, L. (2016). Profil Pasien Baru Infeksi Kandida Pada Kulit dan Kuku. Periodical of Dermatology and Venereology, 28(1), 34-41. https://ejournal.unair.ac.id/BIKK/article/download/2342/1698

Wolff, K. L., \& Johnson, R. A. (2010). Fitzpatrick's Color Atlas \& Synopsis of Clinical Dermatology (6th ed.). McGraw-Hill Companies. 